\title{
MENINGKATKAN KEWIRAUSAHAAN MASYARAKAT MELALUI PELATIHAN KETERAMPILAN PEMBUATAN KONEKTOR MASKER DENGAN TEKNIK MAKRAME SERTA PEWARNAAN TAS/TOTE BAG DENGAN TEKNIK TIE DYE
}

\author{
Muhammad Alvian Hakim ${ }^{1}$, Rika Kurnia Wati ${ }^{2}$, Yazlinda Aulia Maharani ${ }^{3}$, \\ Kusumanindyah Nurul Handayani ${ }^{4}$ \\ ${ }^{1,2,3,4}$ Universitas Sebelas Maret Surakarta \\ ${ }^{4}$ Email: kusumaningdyah_nh@staff.uns.ac.d
}

\begin{abstract}
The increasing number of COVID-19 cases in Indonesia in mid-2021 around June brought increasing adverse effects, one of which was the ongoing economic crisis. This is certainly a problem for SMEs (Small and Medium Enterprises) in Indonesia, among others, such as marketing activities, production development, distribution between consumers are all affected. This community service activity aims to improve the skills and productivity of residents in supporting community entrepreneurial activities in RW 01 Pringtutul Hamlet, Barepan Village. So far, buying and selling activities in the market are not allowed to reduce cases of the spread of COVID-1. Conditions like this force every person to be able to survive in these limited conditions. One thing that can be done is to become a productive human being, even though you are in your own environment as well as at home. This service activity is carried out through counseling and mentoring methods with practice in making mask connectors and decorating bags/tote bags with the "Tie Dye" technique. The participation and enthusiasm of the residents of RW 01 in Pringtutul Hamlet, Barepan Village in participating in a series of activities was very good and active to ask questions and try to do everything that was taught in the training on making connectors and decorating bags/tote bags. The implementation is also carried out by implementing health protocols, namely by not gathering many people, washing hands, using masks and using hand sanitizer. The impact of this service activity is being able to increase creativity, insight and support entrepreneurial activities during the COVID-19 pandemic.
\end{abstract}

Keywords: creativity, entrepreneurship, productive, community service, COVID-19

\begin{abstract}
ABSTRAK
Meningkatnya kasus COVID-19 di Indonesia pada pertengahan tahun 2021 sekitar bulan Juni membawa dampak buruk yang semakin meningkat, salah satunya yaitu krisis ekonomi yang masih berkelanjutan. hal ini tentu menjadi masalah bagi seorang UKM (Usaha Kecil dan Menengah) di Indonesia antara lain, seperti kegiatan pemasaran, pengembangan produksi, distribusi antar konsumen semua terkena dampaknya. Kegiatan pengabdian pada masyarakat ini memiliki tujuan untuk meningkatkan keterampilan dan produktivitas warga dalam menunjang kegiatan kewirausahaan masyarakat RW 01 Dusun Pringtutul, Desa Barepan. Selama ini kegiatan jual beli di pasar tidak diperbolehkan untuk mengurangi kasus persebaran COVID-1. Kondisi yang seperti ini memaksa setiap individu untuk bisa bertahan dalam kondisi yang serba terbatas ini. Salah satu yang bisa dilakukan yaitu menjadi manusia produktif walaupun berada di lingkungan sendiri seperti halnya di rumah. Kegiatan tersebut dilaksanakan melalui metode penyuluhan dan pendampingan dengan praktik dalam membuat konektor masker serta menghias tas/tote bag dengan teknik "Tie Dye". Partisipasi dan antusiasme warga RW 01 di Dusun Pringtutul, Desa Barepan dalam mengikuti serangkaian kegiatan sangatlah baik serta aktif untuk bertanya dan berusaha bisa melakukan segala hal yang diajarkan dalam pelatihan pembuatan konektor serta menghias tas/tote bag. Pelaksanakan juga dilakukan dengan menerapkan protokol kesehatan yaitu dengan tidak mengumpulkan banyak orang, melakukan cuci tangan, menggunakan masker serta menggunakan handsanitizer. Dampak dari kegiatan pengabdian ini yaitu mampu meningkatkan kreatifitas, wawasan serta menunjang kegiatan kewirausahaan di masa pandemi COVID-19.
\end{abstract}

Kata kunci: kreatifitas, kewirausahaan, produktif, pengabdian masyarakat, COVID-19

\section{PENDAHULUAN}

COVID-19 yang berasal dari Wuhan, China menyebabkan pandemi secara global salah satunya di Indonesia. Virus COVID-19 telah menginveksi dan menyebar ke bagian negara lainnya. Pemerintah dan para tenaga medis telah mempelajari virus ini untuk menemukan upaya yang 
tepat dilakukan untuk mengurangi penyebarannya. Penyebaran COVID-19 dapat melalui bersin atau batuk penderita virus COVID-19 yang menempel pada pakaian ataupun alat elektronik (Larasati dan Hariwibowo, 2020). Virus COVID-19 dapat menyerang infeksi saluran pernapasan yang ditandai dengan batuk dan pilek namun lebih bersifat mematikan. Menurut undang-undang nomor 23 tahun 1992 tentang kesehatan upaya kesehatan adalah setiap kegiatan yang dilakukan untuk memelihara dan meningkatkan kesehatan oleh pemerintah dan atau masyarakat. Salah satu upaya mencegah penularan COVID-19 pemerintah mengeluarkan kebijakan baru guna memutus penularan COVID-19 yaitu menerapkan himbauan kepada masyarakat untuk melakukan Physical Distancing dan menghindari kerumunan yang dapat menimbulkan kerumunan.

Desa Barepan merupakan salah satu desa di Kecamatan Cawas, Kabupaten Klaten, Provinsi Jawa Tengah dengan jumlah penduduk per tahun 2020 lebih kurang 2.844 jiwa (Gambar 1). Desa Barepan merupakan daerah yang terdampak pandemi cukup signifikan terutama pada sektor ekonomi. Penduduk Desa Barepan sebagian besar bermata pencaharian sebagai petani dan pengusaha usaha mikro kecil dan menengah dikarenakan Pandemi Covid-19 banyak warga yang terpaksa tidak bekerja karena pengurangan jumlah pekerja di perusahaan.
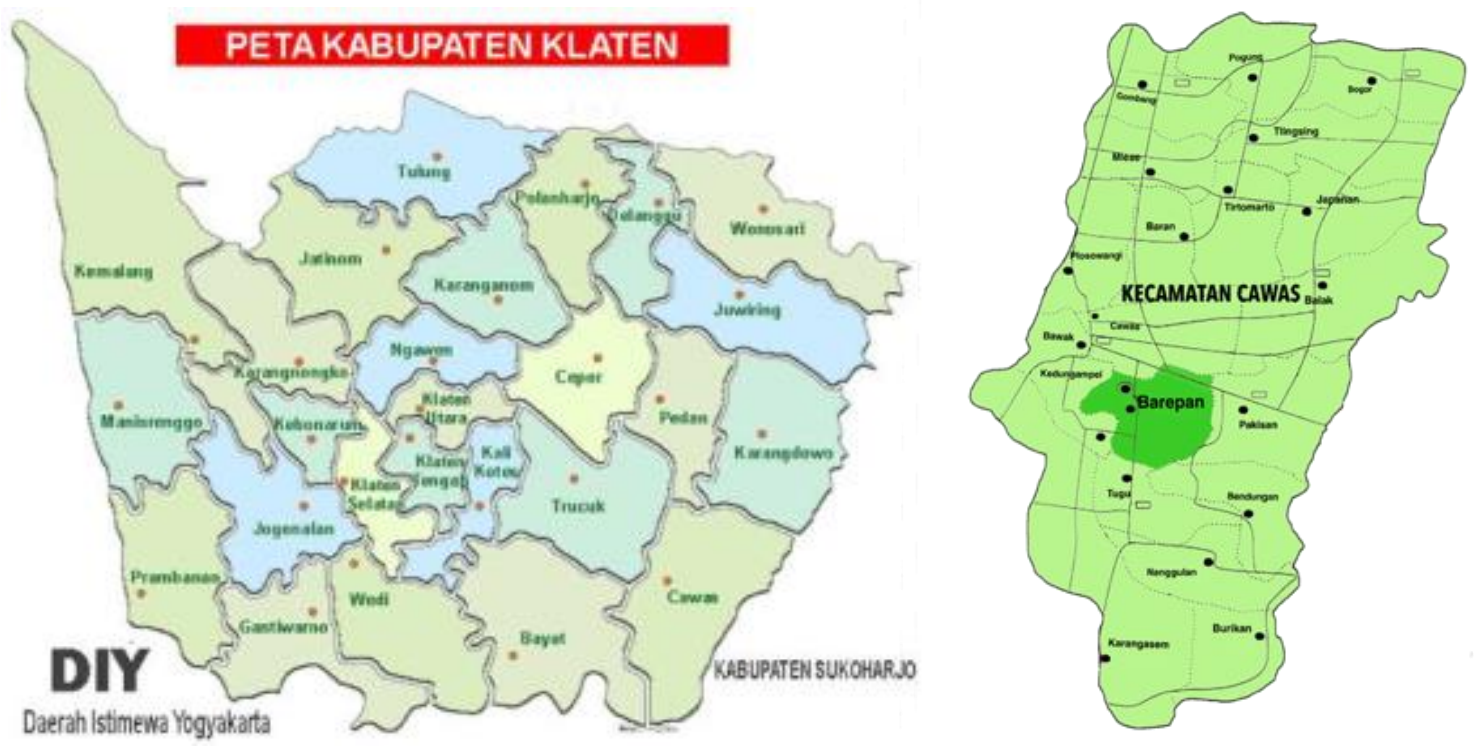

\section{Gambar 1}

Peta Kecamatan Cawas, Kabupaten Klaten

Pandemi yang berkepanjangan memaksa warga Desa Barepan untuk memutar otak untuk mencari sumber pemasukan lain. Salah satu solusi untuk mencari sumber pemasukan lain dapat melalui produk kreatif yang memanfaatkan situasi pandemi. Pengenalan usaha produk kreatif ini dilakukan melalui program Kuliah Kerja Nyata UNS (KKN UNS). Universitas Sebelas Maret (UNS) sebagai salah satu wadah untuk membentuk agen intelektual dengan tugas Tridharma Perguruan Tinggi berupaya mengembangkan program-program kerja desa serta pengabdian kepada masyarakat dengan kegiatan KKN UNS. Kegiatan KKN merupakan kegiatan interaksi sosial yang dapat melibatkan berbagai pihak. Dalam kegiatan KKN, kita dapat melakukan beberapa interaksi sosial, yang dapat diklasifikasikan, yaitu : (1) interaksi antar orang dengan orang lain; (2) interaksi antara orang dengan kelompoknya, dan sebaliknya; dan (3) Interaksi dari satu kelompok dengan kelompok lain (Gunawan, 2000).

Program KKN yang dilakukan oleh mahasiswa UNS merupakan salah satu usaha dan solusi untuk mengatasi permasalahan pada sektor ekonomi warga Desa Barepan. Sebelum memulia 
program, tim KKN telah melakukan pemetaan potensi budaya di Desa Barepan. Pemetaan potensi ini sebagai justifikasi pemilihan program KKN UNS yang diusahakan tepat sasaran memberikan dampak baik secara langsung maupun tidak langsung. Kegiatan edukasi penyuluhan dan pendampingan dengan praktik dalam membuat konektor masker serta menghias tas/tote bag dengan teknik "tie dye" terpilih dikarenakan kebutuhan masyarakat saat ini beradaptasi disituasi Pandemi Covid-19 yang menggunakan masker pada aktivitas sehari-hari serta terpetakannya adanya kegiatan pengembangan kegiatas kerajinan sejenis yaitu membuat konektor masker menggunakan kain perca. Oleh karena itu kami memilih dengan teknik makrame agar menjadi inovasi baru bagi masyarakat yang sudah memiliki keterampilan dasar. Teknik tie dye kami angkat karena produk kerajinan tersebut sangat terkenal dikalangan remaja sehingga dapat meningkatkan kewirausaahan masyarakat. Teknik tie dye atau dapat juga disebut dengan teknik ikat celup merupakan kegiatan yang dilakukan untuk membuat ragam hias di atas permukaan kain yaitu dengan menutup bagian yang tidak diinginkan terkena warna dengan media tekanan yang diakibatkan oleh jahitan atau ikatan (Utomo dkk, 2018). Tas/tote bag adalah jenis tas yang sekarang banyak digemari anak muda dan lagi tren saat ini. Beberapa peluang usaha dari tote bag yaitu: 1) Bahan yang bagus dan motif desain yang variatif akan mampu bersaing dengan produk tote bag lainnya; 2) Upaya unyuk mendukung progam perlindungan terhadap bumi; 3) Banyaknya ibu-ibu muda yang suka dengan produk jaman sekarang; dan 4) Banyaknya target pemasarannya seperti, wisatawan, mahasiswa, dan ibu-ibu muda yang banyak khususnya di daerah-daerah tertentu (Farida dkk, 2020).

Di masa pandemi ini Masyarakat memiliki kebiasaan untuk memakai masker setiap bepergian terkadang mengalami kesulitan saat mengenakan dan melepas masker. Oleh karena itu, masyarakat mulai memakaian konektor masker untuk mengatasi permasalahan tersebut. Kegiatan berikutnya yaitu menghias tas/tote bag dengan teknik "Tie Dye". Inovasi kreatif menjadi peluang usaha yang menjanjikan karena orang cenderung tertarik dengan hal baru atau sesuatu yang tak lazim dijumpai. Produk inovatif seperti menghias tote bag ini dapat meningkatkan harga jual dan meningkatkan daya beli konsumen. Banyaknya warga yang menjadi ibu rumah tangga menjadi sasaran untuk pelatihan ini. Diharapkan melalui pelatihan yang telah dilakukan warga mampu mengisi waktu luang selama pandemi dengan kegiatan yang positif dan bermanfaat. Bahkan tidak menutup kemungkinan setelah melalui pelatihan warga dapat memiliki sumber pendapatan melalui wirausaha pada bidang ini. Wirausaha sangat penting bagi masyarakat dan dapat menjadi solusi agar terjadi suatu peningkatan ke arah yang baik dan perubahan di dalam kualitas hidup dan masyarakat serta dapat berperan signifikan untuk mewujudkan kualitas diri masyarakat yang mandiri. Melalui wirausaha maka akan banyak hal positif yang akan menjadi tambahan bagi masyarakat (Ningsih, R., 2017).

\section{METODE PELAKSANAAN}

Metode kegiatan yang diterapkan dalam kegiatan ini adalah sosialisasi, pelatihan dan pendampingan. Pelaksanaan kegiatan ini dilakukan dengan tiga tahapan, tahap pertama yaitu tahap persiapan. Tahap persiapan kelompok KKN melakukan survei pendahuluan untuk mengetahui seberapa dalam pengetahuan ibu-ibu PKK dalam pembuatan konektor masker dengan teknik makrame dan pewarnaan tas tote bag. Teknik makram dapat di defenisikan sebagai simpul antar beberapa tali Dengan demikian faktor utama dari makrame adalah simpul. "permainan simpul itu akan membentuk bidang dan akhirnya dapat di arahkan untuk membuat benda-benda tertentu, baik benda pakai maupun benda seni (Afriliani, 2018). Tahap selanjutnya merupakan tahapan pelaksanaan kegiatan pembinaan. Tahap pelaksanaan ini kelompok KKN melakukan pendampingan berupa sosialisasi dan pelatihan dalam pembuatan konektor masker dengan teknik makrame dan pewarnaan tas tote bag. Tahap terakhir adalah tahap evaluasi, 
tahapan ini dapat dilihat dari hasil karya yang telah dicapai oleh ibu-ibu PKK dalam pembuatan konektor masker dan pewarnaan tas tote bag berupa pemahaman dan keterampilan mereka. Masukan dan perbaikan dalam pembuatan konektor masker dan pewarnaan tas tote bag dilakukan.

Indikator ketercapaian tujuan kegiatan ini adalah terdapat peningkatan keterampilan ibu-ibu PKK terhadap aspek pemahaman, produksi pembuatan konektor masker dengan teknik makrame dan pewarnaan tas tote bag, memberikan bekal kemampuan bagi ibu-ibu PKK dalam mengembangkan kreativitasnya. Pelaksanaan kegiatan ini dikemas dengan menggunakan pendekatan workshop. Kegiatan dilakukan melalui metode ceramah, diskusi, dan latihan serta evaluasi. Langkah-langkah yang dilakukan dalam pelaksanaan kegiatan ini sebagai berikut.

Pra Acara : Ibu-ibu mencuci tangan dan mengisi daftar hadir terlebih dahulu

Acara : (1). Ibu-ibu PKK diberikan dan diskusi mengenai teknik macrame dalam pembuatan konektor masker dan pewarnaan tas tote bag, (2). Ibu-ibu PKK berlatih untuk membuat konektor masker dengan teknik makrame dan langkah pewarnaan tas tote bag yang sudah dipelajari, (3). Ibu-ibu PKK diberikan bimbingan dalam proses pembuatan konektor dengan teknik makrame dan pewarnaan tas tote bag.

Pasca : (1). Hasil karya pembuatan konektor masker dengan teknik makrame dan pewarnaan tas tote bag dikumpulkan dan dianalisis untuk diberikan masukan atau perbaikan, (2). Evaluasi akhir merupakan evaluasi yang dilakukan secara keseluruhan mulai dari tahap pelatihan dan praktek. Hasil evaluasi akhir ini dapat digunakan untuk menentukan ibu-ibu PKK dapat mandiri atau tidak dalam pembuatan konektor masker dengan teknik makrame dan pewarnaan tas tote bag.

Metode pelaksanaan kegiatan dalam pengabdian kepada Masyarakat yang berjudul "Meningkatkan Kewirausahaan Masyarakat Melalui Pelatihan Keterampilan Pembuatan Konektor Masker dengan Teknik Makrame serta Pewarnaan Tas/Tote bag dengan Teknik Tie Dye" ini dibagi menjadi 3 tahapan, yaitu :

1. Tahap 1 : Metode Ceramah

Kegiatan Pengabdian kepada Masyarakat tentang "Meningkatkan Kewirausahaan Masyarakat Melalui Pelatihan Keterampilan Pembuatan Konektor Masker dengan Teknik Makrame serta Pewarnaan Tas/Tote bag dengan Teknik Tie Dye" diskusi dan tanya jawab. Materi yang diberikan terkait cara pembuatan konektor masker serta menghias tas/tote bag.

2. Tahap 2: Metode Praktik

Kegiatan praktik berupa pelatihan merupakan kegiatan lanjutan dari talkshow yang telah dilakukan. Kegiatan ini dilakukan secara bersama-sama, kelompok KKN membuat dan mempraktekan proses pembuatan konektor masker dengan teknik makrame dan menghias tas/tote bag bersama warga/ peserta. Pada tahap ini, bertujuan peserta dapat melakukan praktik membuat konektor masker dengan teknik makrame dan menghias tas/tote bag secara mandiri dan dilakukan di lingkungan rumah masing-masing.

3. Tahap 3: Evaluasi

Kegiatan evaluasi berupa analisis hasil karya ibu-ibu PKK dalam membuat konektor masker dengan teknik makrame dan menghias tote bag. Hasil karya ibu-ibu yang bagus dan mengembangkannya dapat dianggap mampu membuat secara mandiri dalam pembuatan konektor masker dan menghias tote bag. Pada tahap ini metode evaluasi juga dilakukan dengan cara diskusi tanya jawab seputar pembuatan konektor masker dan pewarnaan tas/tote bag guna dapat memberikan penjelasan serta pemahaman lebih setelah dilakukannya praktik secara langsung oleh ibu-ibu PKK. 


\section{HASIL DAN PEMBAHASAN}

Kegiatan pengandian masyarakat ini merupakan upaya peningkatan keterampilan untuk ibu-ibu PKK Desa Barepan guna dapat meningkatkan kreativitasnya dalam pembuatan konektor masker dengan teknik makrame dan pewarnaan tas tote bag sehingga dapat dijadikan sebagai peningkatan kewirausahaan masyarakat. Target khusus dari kegiatan ini adalah perbaikan keterampilan dan kreativitas untuk manajemen usaha melalui peningkatan keterampilan ibu-ibu PKK dalam pembuatan konektor masker dengan teknik makrame dan pewarnaan tas tote bag . Pelaksanaan kegiatan pelatihan keterampilan pembuatan konektor masker dengan teknik makrame yang telah dilakukan serta pewarnaan tas tote bag, kelompok KKN akan menampilkan beberapa macam teknik makrame dan menjelaskan mengenai alat dan bahan pewarnaan tas tote bag kemudian ibu-ibu memperhatikan dan mempraktekkan. Pelatihan ini berupa pengetahuan dan keterampilan dalam membuat konektor masker dengan berbagai macam teknik makrame serta langkah dalam pewarnaan tas tote bag.. Selama proses pelaksanaan pelatihan tersebut ibuibu PKK menerapkan teknik makrame dan langkah pewarnaan tas tote bag yang telah dipraktekkan oleh mentor. Interaksi antara ibu-ibu PKK dengan penyaji materi dapat dilakukan melalui metode yaitu, sesi tanya jawab.

\section{Proses Kegiatan}

Kegiatan Pengabdian kepada Masyarakat tentang "Meningkatkan Kewirausahaan Masyarakat Melalui Pelatihan Keterampilan Pembuatan Konektor Masker dengan Teknik Makrame serta Pewarnaan Tas/Tote bag dengan Teknik Tie Dye" ini berlangsung dengan baik meskipun ada sedikit kendala teknis. Melalui kegiatan tersebut didapatkan hasil sebagai berikut :

a. Kegiatan pengabdian masyarakat diikuti oleh 15 peserta dari Warga RW 01 Dusun Pringtutul, Desa Barepan, Kecamatan Cawas, Kabupaten Klaten.

b. Kegiatan ini mendapat respon baik dari warga setempat serta semangat dan antusiasme warga dalam mempraktekkan cara pembuatan konektor masker dan tas/tote bag terlihat selama kegiatan berlangsung.

Kegiatan pelaksanaan dalam pengabdian kepada masyarakat dimulai dengan melakukan koordinasi dengan ketua RW (Rukun Warga) 01 Dusun Pringtutul, Desa Barepan, Kecamatan Cawas, Kabupaten Klaten. Agenda pertemuan ini membahas perihal prosedur dan mekanisme pelaksanaan kegiatan pengabdian yang di selenggarakan di Rumah kediaman ketua RW 01 Dusun Pringtutul. Adapun agenda yang dibicarakan antara lain terkait tanggal pelaksanaan, waktu pelaksanan dan sistem pelaksanaan prokes di masa pandemi.

Setelah koordinasi selesai kemudian mendapat izin dan persetujuan dari pihak-pihak yang terlibat antara lain dari perwakilan perangkat desa dan warga setempat. Kemudian dilaksanakan kegiatan pengabdian Masyarakat ini pada hari Minggu, 22 Agustus 2021. Materi yang dibawakan dalam kegiatan ini yaitu tentang "Meningkatkan Kewirausahaan Masyarakat Melalui Pelatihan Keterampilan Pembuatan Konektor Masker dengan Teknik Makrame serta Pewarnaan Tas/Tote bag dengan Teknik Tie Dye".

Pelaksanaan kegiatan dilaksanakan secara luring. Keberlangsungan kegiatan ini berlangsung dengan memperhatikan protokol kesehatan yang ketat antara lain seperti mencuci tangan, menggunakan masker, menggunakan handsanitizer serta tidak mengumpulkan banyak orang, hal ini juga bertujuan dalam rangka mematuhi himbauan pemerintah pada masa pandemi COVID-19 untuk tidak berkerumun dengan jumlah yang skala besar.

Teknis pelaksanaanya dilakukan dengan memberi penyuluhan materi kepada warga RW 01 Dusun Pringtutul, Desa Barepan kemudian dilanjutkan dengan mempraktikan cara pembuatan konektor masker dan tas/tote bag yang dilakukan oleh peserta. Peserta dibagi secara kelompok untuk memudahkan bekerjasama dalam melakukan mentoring. Peserta dibagi menjadi 3 
kelompok yang beranggotakan 5 warga desa serta didampingin oleh 1 mentor yang berasal dari mahasiswa KKN UNS. Mentor mahasiswa bertanggung jawab untuk memberikan pelatihan dari persiapan hingga produk akhir diselesaikan. Mentor mahasiswa dibantu oleh rekan mahasiswa lainnya untuk proses persiapan alat- memperagakan alat - hingga proses praktek.

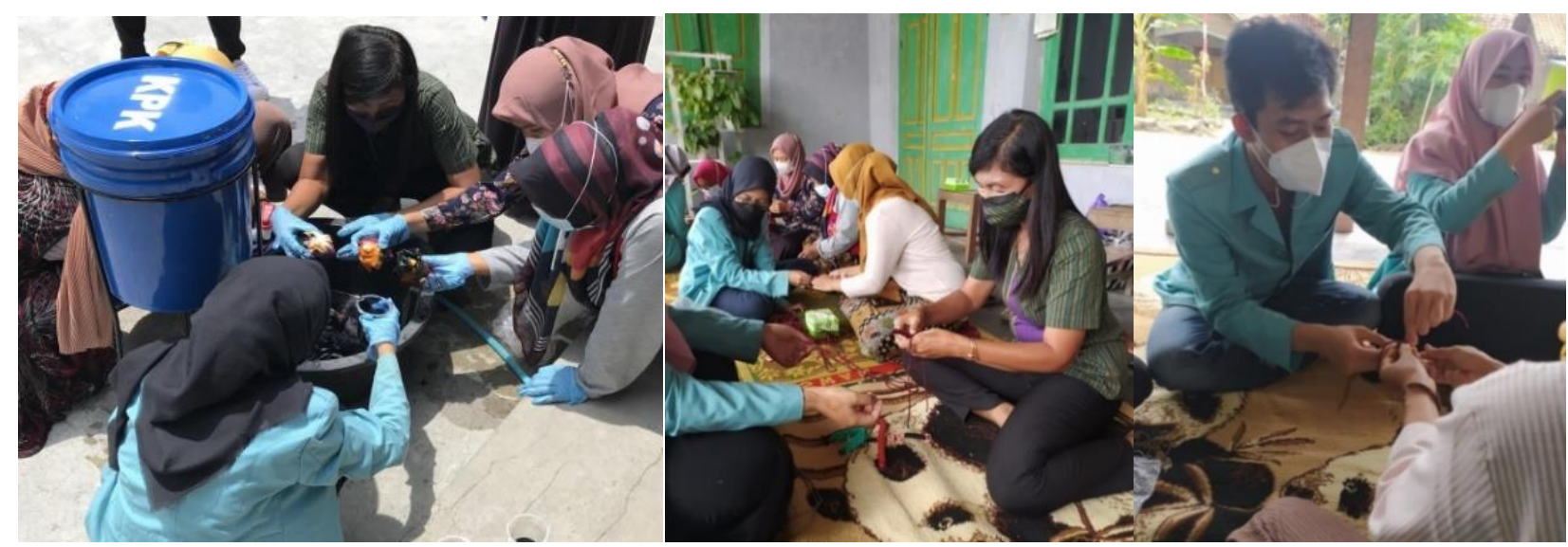

Gambar 2

Pelaksanaan pelatihan pembuatan konektor masker dengan teknik makram Sumber : Kegiatan Lapangan, 2021

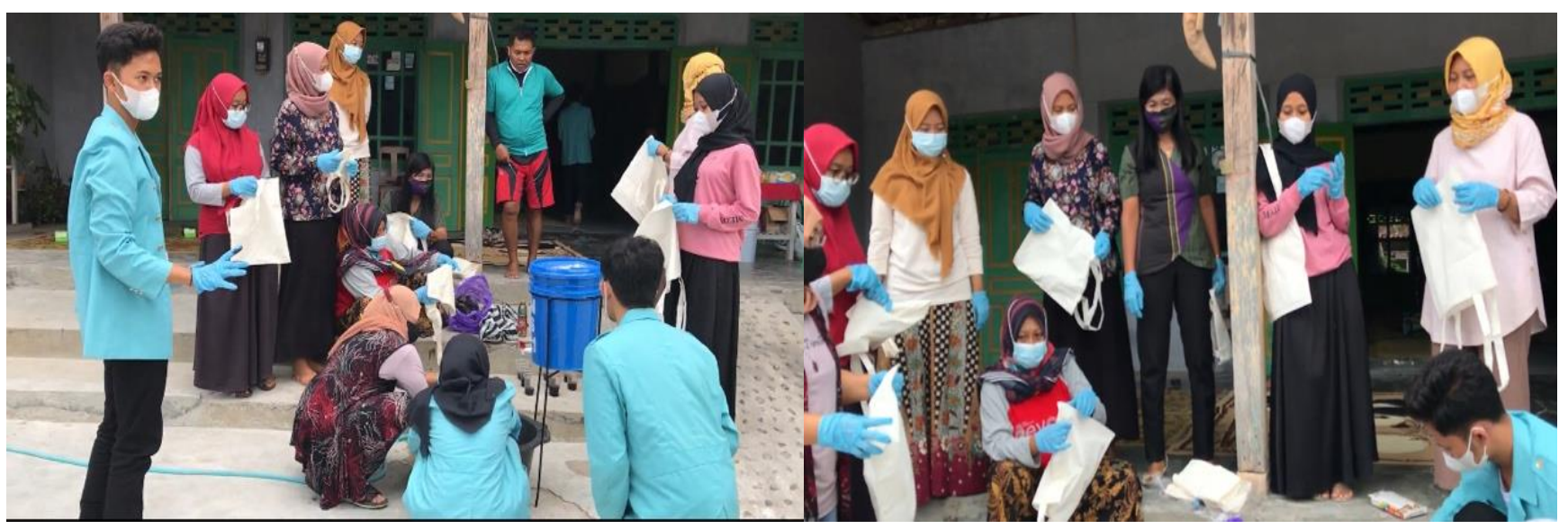

Gambar 3

Persiapan pewarnaan tote bag

Sumber : Kegiatan Lapangan, 2021 

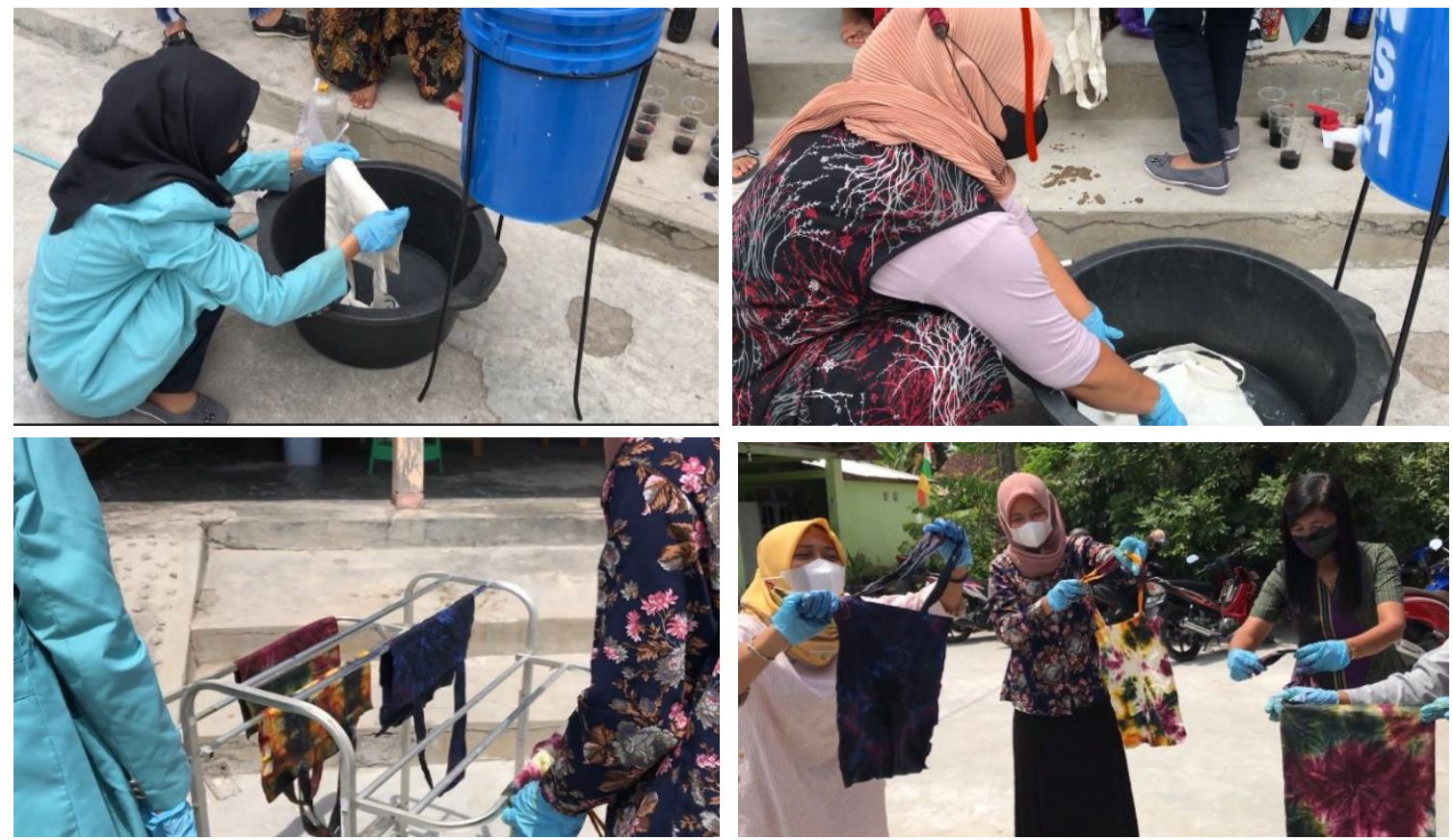

Gambar 4

Proses awal membuat basah tote bag

Sumber: Kegiatan Lapangan, 2021
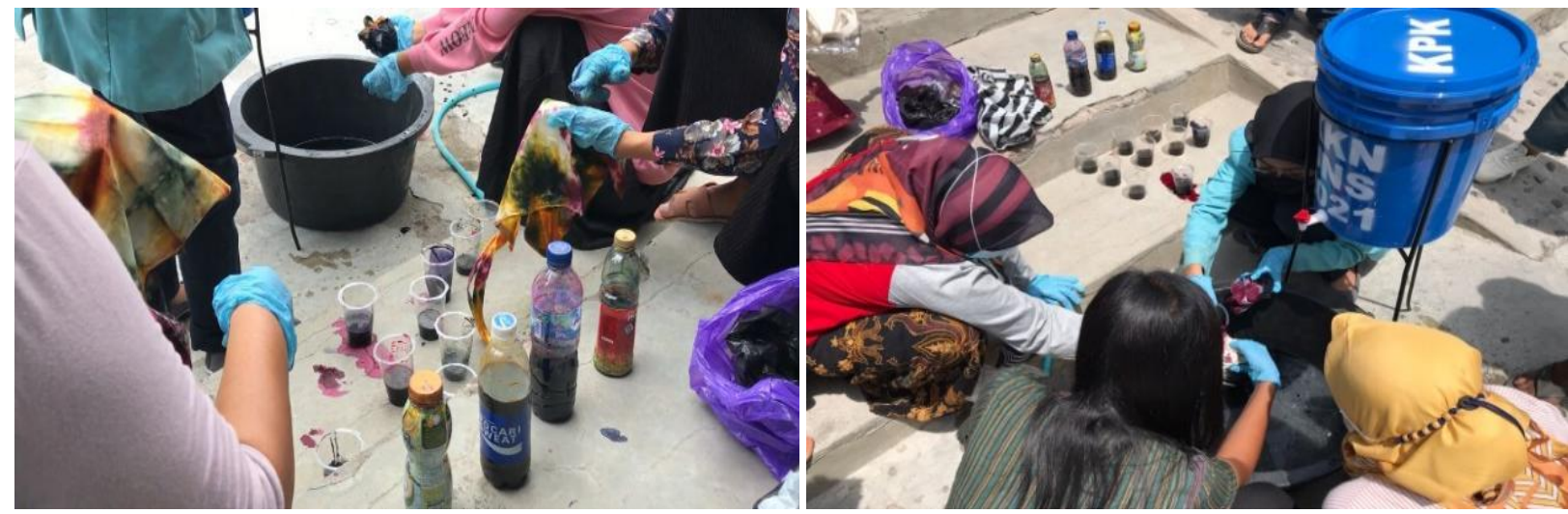

Gambar 5. Proses pewarnaan tote bag

Sumber : Kegiatan Lapangan, 2021

\section{Pembahasan}

Kegiatan pembuatan konektor masker dengan teknik makram bukan hal yang baru bagi para peserta di kegiatan ini. Termasuk juga kerajinan praktek pewarnaan textile. Praktek kerajinan tangan tersebut umunya, sudah sering dilakukan oleh ibu-ibu PKK dan remaja, oleh karenanya tanpa kendala berarti para peserta dapat mengikuti kegiatan praktek. Intervensi mengenalkan kreatifitas teknik kerajinan baru dari mahasiswa KKN UNS menjadi penambahan wawasan dan pengalaman yang baru bagi warga.

Pembuatan konektor masker menggunakan teknik makrame karena teknik makrame merupakan salah satu teknik dalam pengolahan tekstil. Makrame sendiri merupakan seni simpul menyimpul 
tali yang di susun disimpulkan membentuk sebuah karya yang indah, teknik ini tidak hanya untuk pembuatan konektor masker namun juga dapat digunakan untuk pembuatan benda fungsional lainnya seperti tas, gantungan kunci, hiasan dinding, dan tirai. Konektor masker saat ini mayoritas terbuat dari kain yang dijahit, untuk itu kami memiliki inovasi lain memilih konektor masker melalui Teknik makrame ini guna menambah variasi masyarakat dalam berbagai macam konektor masker yang ada. Untuk bahan konektor masker makrame dapat dicari di toko alat jahit.

Proses pembuatan konektor masker dan pewarnaan totebag dilakukan dengan porsi jam mentoring yang berbeda. Proses pemaparan materi dilakukan kurang lebih sekitar 1 jam dengan menjelaskan alat dan bahan yang digunakan dalam kegiatan membuat kerajinan tersebut serta langkah pembuatannya. Proses selanjutnya yaitu praktik yang memerlukan waktu kurang lebih 2 jam. Pembuatan konektor masker mengambil porsi praktek kerja yang tidak memakan waktu berbanding proses kegiatan pewarnaan tote bag. Sebaliknya pada persiapan pewarnaan tote bag dibutuhkan waktu yang cukup untuk menyiapkan bahan pewarnaan, melakukan proses perendaman/ pencelupan bahan tas yang akan diwarna di dalam air. Proses ini menjadi penting agar warna yang dikenakan pada bahan tas dapat terserap dengan baik hingga keserat bahan tas serta proses pengikatan tas dengan karet gelang yang bertujuan untuk mengisolasi warna yang disebut juga teknik pewarnaan "Tie Dye". Teknik pewarnaan tie dye membutuhkan waktu yaitu pada proses mengikat tas menggunakan karet sebelum dicelupkan pada ember pewarnaan. Proses pengikatan digunakan untuk mengisolasi warna untuk area yang tidak terwarna, sehingga area yang tidak terwarna menjadi pattern khas desain tote bag.

Dari beberapa kegiatan yang dilaksanakan, dapat dilihat bahwa peserta kegiatan lebih antusias pada saat kegiatan edukasi totebag. Hal tersebut disebabkan karena pewarnaan tas tersebut dilakukan melalui proses menarik yang pada awalnya hanya tas putih polos menjadi beragam warna yang motifnya didapatkan secara acak melalui ikatan dan celupan ke pewarnanya. Antusias tersebut dapat dilihat dari ekspresi dan semangat peserta saat kegiatan membuka ikatan tas yang sudah dicelup dan kebetulan berhasil dokumentasikan pada saat momen tersebut. Selain itu ide pewarnaan totebag bermotif Tie Dye ini juga masih menjadi suatu hal baru yg diketahui oleh peserta, sehingga kedepannya dapat menjadi alternatif peluang usaha di desa.

Bahan pewarnaan tote bag mudah didapat. Pewarna dan penguat warna dapat dibeli di Desa Jarum Bayat Klaten di usaha batik milik warga, karena sebagian besar warga disana memiliki home industri batik sendiri. Untuk totebag polos dapat di pesan online atau dijahitkan sendiri. Sedangkan untuk handgloves, ember dan gelang dapat ditemukan di swalayan. Alasan mahasiswa memilih edukasi dengan teknik makrame dan tie dye ini sebagai program kerja KKN adalah karena masyarakat sudah mengembangkan kerajinan yang serupa yaitu membuat konektor masker dengan kain perca sedangkan menghias tas dengan teknik tie dye dikarenakan tie dye merupakan salah satu teknik batik yang proses pengerjaannya mudah yaitu dengan mengikat atau pembentukan motif menggunakan karet kemudian dituangkan pewarna di atasnya. Tie dye sendiri juga sempat menjadi trend fashion tahun kemarin jadi banyak masyarakat yang sudah mengetahui dan paham. untuk pewarnanya sendiri sangat hemat karena hanya digunakan sedikit sudah bisa untuk belasan tote bag. Pelatiahan pembuatan kerajinan ini merupakan ide yang termasuk hal baru sehingga dapat menjadi salah satu peluang usaha yang jarang ditemukan di sekitar Desa Barepan terutama di Lapangan Barepan sebagai sarana khusus warga Barepan untuk melakukan wirausaha.

\section{Hasil Evaluasi}


Akhir kegiatan pengabdian masyarakat dilakukan evaluasi proses kegiatan. Evaluasi dilakukan dengan melakukan observasi respon warga. Adapun beberapa hal yang dapat diamati diantaranya adalah

1. Melihat respon warga terhadap pemahaman materi yang disampaikan

Peserta kegiatan merespon dengan baik pada proses pemberian materi. Warga dapat dengan mudah menerima arahan atau pendampingan secara langsung baik dalam pembuatan konektor masker dan pewarnaan tas/tote bag

2. Keaktifan dalam diskusi

Peserta kegiatan terlihat antusias dengan proses kegiatan pengabdian masyarakat, terbukti dalam diskusi diakhir, peserta kegiatan - ibu-ibu PKK tidak merasa kesulitan dalam pembuatan kerajinan tersebut. Ibu-ibu PKK memperoleh informasi dan keterampilan baru mengenai pembuatan konektor masker dengan teknik makrame dan pewarnaan tas dengan teknik tie dye mulai dari bahan yang baik untuk digunakan dan langkah membuat kerajinan tersebut.

3. Opini yang disampaikan oleh warga terkait prose pengabdian masyarakat

Peserta memberikan opini atau tanggapan di akhir kegiatan. Peserta kegiatan merasa terbantu dengan program pelatihan pembuatan konektor masker dan pewarnaan tas tie dye. Program ini sangat bermanfaat bagi mereka karena memiliki ide pengembangan kerajinan tangan. Ide diservikasi produk diharapkan nantinya dapat menjadi alternatif pengembangan produk mereka atau bahkan menjadi peluang kewirausahaan yang tentunya dapat membantu perekonomian. Kegiatan ini bisa menjadi peluang kewirausahaan baru apabila didukung dengan bahan baku yang lebih berkualitas serta didukung dengan tambahan bermacammacam motif dalam pembuatan konektor masker dan pewarnaannya tas/tote bag.

\section{KESIMPULAN DAN SARAN}

Berdasarkan hasil pemaparan pada hasil penjelasan tersebut, kesimpulan yang dapat diberikan yaitu sebagai berikut

1. Pembuatan kerajinan konektor masker dapat meningkatkan serta membuka peluang kewirausahaan warga. Hal ini berkesesuaian dengan tujuan praktis kegiatan, yaitu pembekalan keterampilan berbagai macam teknik makrame untuk membuat konektor masker dapat membuat deservikasi produk usaha sebelumnya serta peluang usaha baru. Hal ini tentu saja dapat berdampak meningkatkan produktivitas dan penghasilan masyarakat. Melalui pelatihan ini diharapkan ibu-ibu PKK juga dapat melakukan pendampingan kepada ibu-ibu lainnya di lingkungan setempat.

2. Kegiatan pelatihan keterampilan dapat membantu mengatasi permasalahan ekonomi warga desa yang disebabkan karena adanya Pandemi Covid-19. Salah satunya dengan menanamkan semangat berwirausaha secara kecil-kecilan melalui pemanfaatan fasilitas yang tersedia di wilayah setempat.

3. Pelaksanaan pelatihan keterampilan ini diharapkan dapat dilakukan secara berkelanjutan secara mandiri oleh warga. Mengingat pelatihan ini bisa dilakukan secara mandiri, mudah dan ketersediaan bahan yang mudah didapat. Kegiatan ini merupakan tahap awal dari seluruh rangkaian kegiatan yang dapat diberikan dari kelompok KKN UNS sebagai upaya pengembangan keterampilan dan kreativitas yang diberikan pada masyarakat.

4. Saran pengembangan kedepannya, diharapkan ibu-ibu PKK Desa Barepan dapat lebih kaya dan kreatif mengembangan teknik dasar yang telah disampaikan oleh kelompok KKN UNS. 


\section{Ucapan Terima Kasih}

Ucapan terima kasih dan penghargaan setinggi-tingginya juga disampaikan kepada Universitas Sebelas Maret Surakarta, Unit Pelaksanaan Kuliah Kerja Nyata (UPKKN), Lembaga Penelitian dan Pengabdian Kepada Masyarakat (LPPM) UNS Surakarta yang telah memfasilitasi pelaksanaan kegiatan KKN periode Juli-Agustus 2021. Ucapan terimakasih kepada tim KKN Andri Ardiansyah, Archaya Rastra Sewakottama Soekotjo, Derra Ananda Margaretta, Fausan Arya Rajasa, Fauzi Septyarahman, Retnu Sipparamita. Mengucapkan terimakasih kepada Dosen Pembimbing Lapangan, Dr. Eng Kusumaningdyah N.H, ST, MT yang telah mendampingi serta memberi masukan dari setiap program kegiatan yang berlangsung. Ucapan terimakasih juga ditujukan kepada para pihak yang berkontribusi dalam kegiatan ini, baik dari warga RW 01 Dusun Pringtutul dan Perangkat Desa Barepan, atas partisipasi dan kerjasama yang baik selama ini. Atas dukungan, partisipasi dan kerja sama yang diberikan, Akhirnya kami dapat menyelesaikan tugas Kuliah Kerja Nyata Tematik periode Juli-Agustus 2021 sehingga dapat terlaksana dengan baik dan lancar.

\section{REFERENSI}

Afriliani, Laila. 2018. Wpap Pada Tas Dengan Teknik Makrame Dan Tapestri. Skripsi. Padang : Universitas Negeri Padang.

Farida, Nurul, dkk. 2020. Pembuatan Kantong Kain "Tote Bag” Sebagai Pengganti Kantong Plastik Pada Pemuda Wirausaha Blitar. Jurnal Graha Pengabdian, 2(4)

Gunawan, Ary H. 2000. Sosiologi Pendidikan. Jakarta: Rineka Cipta.

Larasati, Annisa Lazuardi dan Chandra Hariwibowo. 2020. Penggunaan Desinfektan dan Antiseptik pada Pencegahan Penularan Covid-19 di Masyarakat. Majalah farmasetika. $5(3)$

Ningsih, R. 2017. Peranan Pendidikan Kewirausahaan dalam Meningkatkan Motivasi Berwirausaha bagi Mahasiswa. Prosiding Diskusi Panel Nasional Pendidikan Kewirausahaan" Memajukan Kewirausahaan dalam upaya membangun Indonesia, pp.60-69

Utomo, agus prasetyo, dkk. 2018. Desain Video Tutorial Teknik Tie Dye Dengan Pewarna Alami Warna Biru Indigofera Dan Kuning Jalawe. Jurnal IKRA-ITH. 2(3) 